УДК 629.7.02

УДК 629.7.04

Шаламов А. Н.

GECI GmbH. Германия, г. Гамбург

\title{
АНАЛИЗ ТОПЛИВНОЙ ЭФФЕКТИВНОСТИ НОВЕЙШИХ ПАССАЖИРСКИХ САМОЛЁТОВ
}

Проведён анализ топливной әффективности новейших пассажирских самолётов. Определены наиболее экономичные модели узкофюзеляжных самолётов вместимостью 100...149 и 150 ...199 пассажиров в двухклассной компоновке пассажирского салона. Определены наиболее экономичные модели широкофюзеляжных самолётов вместимостью $300 . . .399$ и 400 ...600 пассажсиров в трёхклассной компоновке пассажирского салона. [dx.doi.org/10.29010/080.5]

Ключевые слова: топливная эффективность самолёта; пассажирский самолёт; узкофюзеляжный самолёт; широкофюзеляжный самолёт; проектирование самолётов.

\section{Введение}

В настоящее время к пассажирским самолётам предъявляется ряд противоречивых требований конструктивного, технологического, экологического и эксплуатационного характера. Одним из важнейших критериев оценки эффективности пассажирских самолётов является коэффициент топливной эффективности, который выражает количество топлива, необходимое для транспортировки одного пассажира при заданных условиях комфорта в салоне самолёта на заданное расстояние.

На протяжении последних 60 лет производители пассажирских самолётов борются за снижение показателей коэффициента топливной эффективности [1], т.е. за более высокую топливную эффективность, которая в свою очередь оказывает существенное значение на стоимость авиационных перевозок.

\section{Постановка задачи}

Целью настоящей статьи является анализ топливной эффективности новейших пассажирских узкои широкофюзеляжных самолётов, их сравнение с существующими пассажирскими самолётами и определение наиболее экономичных самолётов, эксплуатация которых позволяет обеспечить минимальные затраты топлива при пассажирских воздушных перевозках.

\section{Изложение основного материала исследования}

Критерием, определяющим топливную эффективность пассажирского самолёта, является коэффициент топливной эффективности:

$$
k_{m \ni}=\frac{Q_{m}}{n_{\text {nacc }} \cdot L},
$$

где $k_{m э}$ - коэффициент топливной эффективности пассажирского самолёта, л/(пасс·км);

$Q_{m}$ - объём топлива, л;

$n_{\text {nacc }}-$ количество пассажиров на борту, пасс.;

$L$ - дальность полёта, км.

Коэффициент топливной эффективности является комплексным показателем, отражающим достижения в области технологии самолёто- и двигателестроения, проектирования и производства систем самолётов (таких как система управления, топливная, гидравлическая, электрическая и т.д.), а также в области общего проектирования самолётов.

Bce современные пассажирские самолёты можно разделить на две группы: узкофюзеляжные и широкофюзеляжные.

\section{Анализ топливной эффективности новейших узкофюзеляжных самолётов}

В последнее время разработаны следующие узкофюзеляжные пассажирские самолёты:

- Bombardier CS100 (см. рисунок 1);

- Bombardier CS300 (см. рисунок 2);

- СОМАС С919 (см. рисунок 3);

- «Иркут» МС-21-300 (см. рисунок 4).

Самолёты компании Bombardier CS100 и CS300 уже находятся в стадии серийного производства и эксплуатации. Компанией, первой начавшей выполнять регулярные рейсы на самолётах CS100, является швейцарская Swiss Global Air Lines, 


\section{3/2017 ТехнологическиЕ ТC}

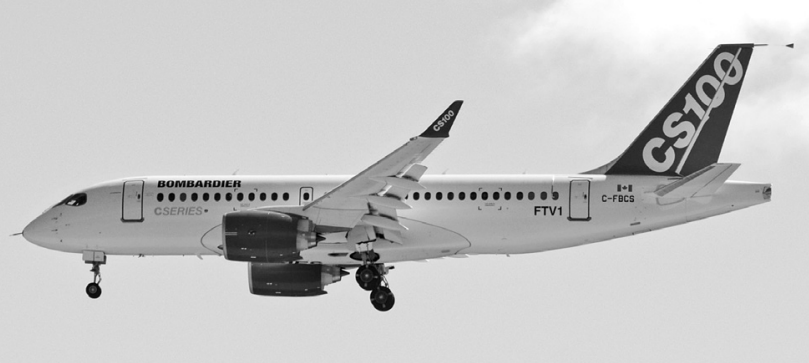

Рис. 1. Самолёт компании Bombardier CS100

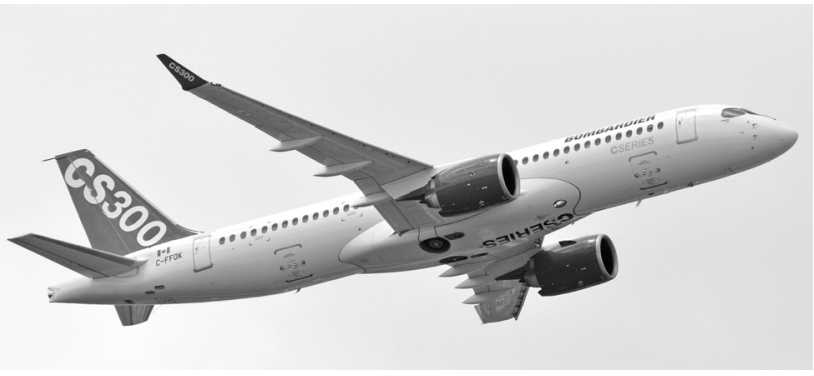

Рис. 2. Самолёт компании Bombardier CS300

а CS300 начала эксплуатировать латвийская авиакомпания Air Baltic. Обе компании приступили к эксплуатации указанных самолётов в 2016 году [2] и [3].

Самолёты СОМАС С919 и «Иркут» МС-21-300 уже совершили первые полёты (5 и 28 мая 2017 года соответственно) [4] и [5], но в настоящее не эксплуатируются авиакомпаниями, так как ещё не прошли полный цикл необходимых испытаний. Вместе с тем, наряду с самолётом МС-21-300 разрабатывается и планируется к производству и последующей эксплуатации ещё одна модификация МС-21-200 (см. рисунок 5). В данном разделе статьи анализируется топливная эффективность узкофюзеляжных пассажирских самолётов компаний Bombardier (CS100 и CS300), COMAC C919

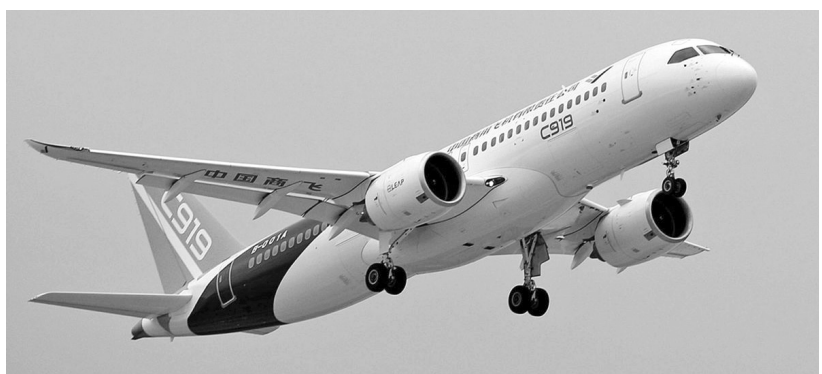

Рис. 3. Самолёт компании СОМАС С919

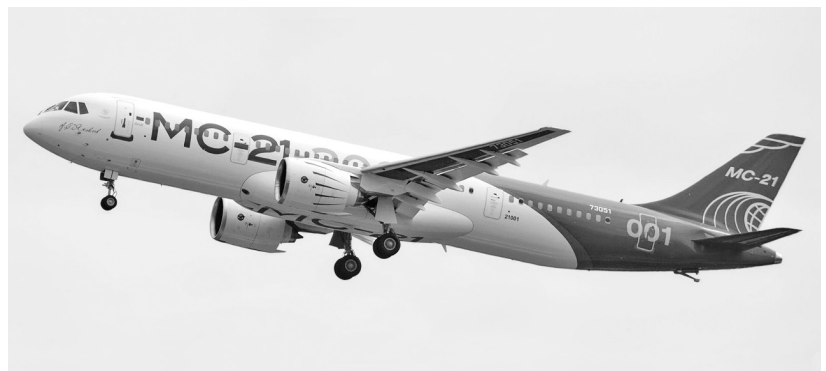

Рис. 4. Самолёт компании Иркут МС-21-300

и корпорации «Иркут» (МС-21-200 и МС-21-300), несмотря на то, что самолёт МС-21-200 ещё окончательно не разработан.

Анализ топливной эффективности указанных самолётов представлен в таблице 1 , данные для расчётов взяты из [6], [7] и [8].

Учитывая классификацию деления узкофюзеляжных пассажирских самолётов в зависимости от их вместимости [9], проведено сравнение топливной эффективности новейших узкофюзеляжных пассажирских самолётов с существующими самолётами в каждой группе. Результаты расчётов представлены в таблицах 2-7.

По результатам расчётов и сравнения показателей топливной эффективности самолётов представляется возможным констатировать следующее.

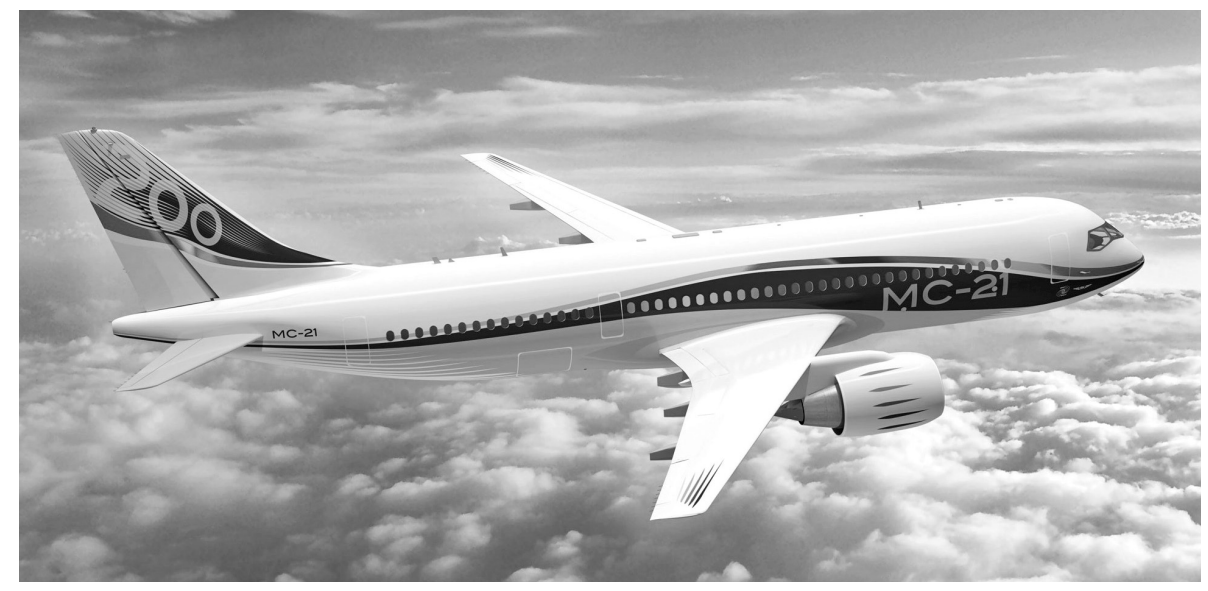

Рис. 5. Самолёт компании Иркут МС-21-200 


\section{Анализ топливной эффективности пассажирских самолётов CS100, CS300, C919ER, MC-21-200 и MC-21-300}

\begin{tabular}{|c|c|c|c|c|}
\hline Самолёт & $\boldsymbol{Q}_{\mathrm{r}}$ & $\boldsymbol{L}$ & $\boldsymbol{n}_{\text {пасс }}$ & $\boldsymbol{k}_{\text {тә }}$ \\
\hline- & {$[л]$} & {$[$ км] } & {$[$ пасс] } & {$[$ л/(пасс·км $]$} \\
\hline CS100 & 22038 & 5741 & 108 & 0.0355436 \\
\hline CS300 & 21516 & 6112 & 130 & 0.0270791 \\
\hline MC-21-200 & 25500 & 6400 & 132 & 0.0301847 \\
\hline C919ER & 24450 & 5555 & 158 & 0.0278572 \\
\hline MC-21-300 & 25500 & 6000 & 163 & 0.0260736 \\
\hline
\end{tabular}

* ER - extended range

Самолёт компании Bombardier CS100 (см. таблицу 4) показывает значение коэффициента топливной эффективности 0,0355436 л/(пасс·км) и превосходит самолёт компании Airbus A318-100SL на 7,89\% и самолёт компании Boeing 737-600WL на $13,54 \%$. При этом при одинаковой вместимости с 737-600WL CS100 уступает ему в дальности полёта (5741 км против 5970 км). Дальность полёта самолёта A318-100SL составляет 5900 км, что также превосходит дальность полёта самолёта CS100. Однако, принимая во внимание общую тенденцию по снижению расхода топлива, самолёт CS100 является более предпочтительным для авиакомпаний. Кроме того, для компаний, эксплуатирующих самолёт, например, в пределах Европы, полёты с максимальной дальностью являются крайне редки- ми, поэтому для перевозки пассажиров на внутриевропейских рейсах проигрышем самолёта CS100 в дальности полёта по сравнению с конкурирующими самолётами можно пренебречь.

Сравнение топливной эффективности самолёта CS300 (см. таблицу 5) с показателями конкурирующих самолётов показывает, что самолёт CS300 превосходит самолёт A319-100SL на 30,3\%, самолёт 737-700WL на 19,72\%, самолёт MC-21-200 на $11,47 \%$ и слегка (на 0,3\%) превосходит самолёт A319nео. Превосходство над самолётом 737MAX7 составляет 8,03\%. Вместе с тем, CS300 уступает в дальности полёта всем конкурирующим самолётам. Однако, как и в случае с самолётом CS100, принимая во внимание условия эксплуатации, авиакомпании этим недостатком могут пренебречь. Следует

Таблица 2

Анализ топливной эффективности пассажирских самолётов компании Airbus

\begin{tabular}{|c|c|c|c|c|}
\hline Самолёт & $\boldsymbol{Q}_{\mathbf{r}}$ & $\boldsymbol{L}$ & $\boldsymbol{n}_{\text {пасс }}$ & $\boldsymbol{k}_{\text {гэ }}$ \\
\hline- & {$[л]$} & {$[$ км] } & {$[$ пасс] } & [л/(пасс·км)] \\
\hline A318-100SL & 24210 & 5900 & 107 & 0.0383494 \\
\hline A319-100SL & 30190 & 6900 & 124 & 0.0352852 \\
\hline A320-200SL & 27200 & 6100 & 150 & 0.0297268 \\
\hline A321-200SL & 30030 & 5900 & 185 & 0.0275126 \\
\hline A319neo & 29659 & 7800 & 140 & 0.0271603 \\
\hline A320neo & 29659 & 6900 & 165 & 0.0260509 \\
\hline A321neoLR & 32676 & 7400 & 206 & 0.0214353 \\
\hline
\end{tabular}

* SL - sharklets, LR - long range 
Анализ топливной эффективности пассажирских самолётов компании Boeing

\begin{tabular}{|c|c|c|c|c|}
\hline Самолёт & $\boldsymbol{Q}_{\mathbf{r}}$ & $\boldsymbol{L}$ & $\boldsymbol{n}_{\text {пасс }}$ & $\boldsymbol{k}_{\text {тэ }}$ \\
\hline- & {$[л]$} & {$[$ км] } & {$[$ пасс] } & {$[$ л/(пасс·км)] } \\
\hline $737-600 \mathrm{WL}$ & 26020 & 5970 & 108 & 0.0403561 \\
\hline $737-700 \mathrm{WL}$ & 26020 & 6370 & 126 & 0.0324188 \\
\hline $737-800 \mathrm{WL}$ & 26020 & 5765 & 160 & 0.0282090 \\
\hline $737-900 \mathrm{ERWL}$ & 29660 & 6045 & 174 & 0.0281985 \\
\hline $737 \mathrm{MAX7}$ & 25941 & 7038 & 126 & 0.0292528 \\
\hline $737 \mathrm{MAX8}$ & 25941 & 6704 & 162 & 0.0238857 \\
\hline $737 \mathrm{MAX9}$ & 25941 & 6658 & 180 & 0.0216456 \\
\hline
\end{tabular}

* $\mathrm{WL}-$ winlets

Таблица 4

Сравнение показателей топливной эффективности самолёта CS100 с конкурирующими самолётами

\begin{tabular}{|c|c|c|c|c|}
\hline Самолёт & $\boldsymbol{k}_{\text {тэ }}$ & Самолёт & $\boldsymbol{k}_{\text {тэ }}$ & Разница \\
\hline- & {$[\pi /($ пасс·км $)]$} & - & $[$ л/(пасс·км $)]$ & $\%$ \\
\hline $\mathrm{CS} 100$ & 0.0355436 & $\mathrm{~A} 318-100 \mathrm{SL}$ & 0.0383494 & 7.89 \\
\hline $\mathrm{CS} 100$ & 0.0355436 & $737-600 \mathrm{WL}$ & 0.0403561 & 13.54 \\
\hline
\end{tabular}

также отметить, что по пассажировместимости в двухклассной компоновке пассажирского салона самолёт CS300 превосходит A319-100SL на 6 мест (130 пассажиров против 124), 737-700WL на 4 места (130 пассажиров против 126) и 737MAX с такими же, как и в случае с 737-700WL, показателями. Вместе с тем он уступает в части пассажиро- вместимости МС-21-200 2 места (130 против 132) и 10 мест A319neo (130 против 140).

Анализ топливной эффективности самолёта компании СОМАС С919 (см. таблицу 6) показывает, что он является более экономичным по сравнению с самолётом A320-200SL на 6,71\%, одновременно проигрывая ему в дальности полёта (5555 км

Таблица 5

Сравнение показателей топливной эффективности самолёта CS300 с конкурирующими самолётами

\begin{tabular}{|c|c|c|c|c|}
\hline Самолёт & $\boldsymbol{k}_{\text {гә }}$ & Самолёт & $\boldsymbol{k}_{\text {гә }}$ & Разница \\
\hline- & {$[л /($ пасс·Км $]$} & - & $[$ лл/(пасс·км $)]$ & $\%$ \\
\hline CS300 & 0.0270791 & A319-100SL & 0.0352852 & 30.3 \\
\hline CS300 & 0.0270791 & $737-700 \mathrm{WL}$ & 0.0324188 & 19.72 \\
\hline CS300 & 0.0270791 & MC-21-200 & 0.0301847 & 11.47 \\
\hline CS300 & 0.0270791 & A319neo & 0.0271603 & 0.3 \\
\hline CS300 & 0.0270791 & 737MAX7 & 0.0292528 & 8.03 \\
\hline
\end{tabular}




\section{Сравнение показателей топливной эффективности самолёта C919ER с конкурирующими самолётами}

\begin{tabular}{|c|c|c|c|c|}
\hline Самолёт & $\boldsymbol{k}_{\text {тэ }}$ & Самолёт & $\boldsymbol{k}_{\text {гә }}$ & Разница \\
\hline- & {$[л /($ пасс·Км $]$} & - & {$[$ лл $($ пасс·км $)]$} & $\%$ \\
\hline C919ER & 0.0278572 & A320-200SL & 0.0297268 & 6.71 \\
\hline C919ER & 0.0278572 & $737-800 \mathrm{WL}$ & 0.0282090 & 1.26 \\
\hline C919ER & 0.0278572 & A320neo & 0.0260509 & -6.48 \\
\hline C919ER & 0.0278572 & 737 MAX8 & 0.0238857 & -14.26 \\
\hline C919ER & 0.0278572 & MC-21-300 & 0.0260736 & -6.4 \\
\hline
\end{tabular}

Таблица 7

Сравнение показателей топливной эффективности самолёта МС-21-300 с конкурирующими самолётами

\begin{tabular}{|c|c|c|c|c|}
\hline Самолёт & $k_{\text {тә }}$ & Самолёт & $k_{\text {тэ }}$ & Разница \\
\hline- & [л/(пасс·км)] & - & [л/(пасс·км)] & $\%$ \\
\hline MC-21-300 & 0.0260736 & A320-200SL & 0.0297268 & 14.01 \\
\hline MC-21-300 & 0.0260736 & 737-800WL & 0.0282090 & 8.19 \\
\hline MC-21-300 & 0.0260736 & A320neo & 0.0260509 & -0.09 \\
\hline MC-21-300 & 0.0260736 & 737MAX8 & 0.0238857 & -8.39 \\
\hline
\end{tabular}

против 6100 км), но выигрывая в пассажировместимости (158 пассажиров против 150 в двухклассной компоновке пассажирского салона). Также самолёт С919 превосходит в части топливной эффективности самолёт 737-800WL на 1,26\%, но уступает ему в дальности полёта (5555 км против 5765 км) и также незначительно уступает ему в пассажировместимости (158 пассажиров против 160). Сравнение с самолётом A320nео показывает полное превосходство европейской машины в части топливной эффективности (С919 уступает A320neo 6,48\%), дальности полёта (6900 км у A320nеo против 5555 км у С919) и пассажировместимости (165 пассажиров у A320nео против 158 у С919). Также самолёт С919 по всем трём параметрам уступает самолёту 737MAX8 (в части топливной эффективности на 14,26\%, в дальности полёта с 5555 км против 6704 км и пассажировместимости со 158 пассажирами против 162). Также самолёт С919 уступает самолёту МС-21-300 по всем трём параметрам (6,4\% в части топливной эффективности, по дальности полёта с 5555 км против 6000 км и пассажировместимости со 158 пассажирами против 163).

Самолёт компании «Иркут» МС-21-300 (см. таблицу 7) имеет величину коэффициента топлив- ной эффективности 0,0260736 л/(пасс·км) и превосходит в этой части самолёт A320-200SL на $14,01 \%$, незначительно уступая ему в дальности полёта (6000 км против 6100 км), но превосходя в части пассажировместимости (163 пассажира против 150). Сравнение самолётов МС-21-300 и $737-800 \mathrm{WL}$ демонстрирует превосходство MC-21-300 по всем трём параметрам (8,19\% в части топливной эффективности, по дальности полёта 6000 км против 5765 км и в части пассажировместимости 163 пассажира против 160). Вместе с тем самолёт MC-21-300 уступает самолёту A320nеo по всем трём параметрам $(0,09 \%$ по топливной эффективности, существенно по дальности полёта 6000 км против 6900 км и незначительно в части пассажировместимости - 163 пассажира против 165). Сравнение МС-21-300 с 737МАХ8 показывает худшую на $8,39 \%$ топливную эффективность, существенный проигрыш в дальности полёта (6000 км против 6704 км) и незначительно большую пассажировместимость (163 пассажиров против 162).

В целом можно констатировать, что в своём классе самолёт CS100 превосходит своих конкурентов (A318-100SL и 737-600WL) в части топлив- 
ной эффективности, но незначительно проигрывает им в дальности полёта. В части пассажировместимости самолёт держит паритет с конкурентами. Самолёт CS300 превосходит всех своих конкурентов в части топливной эффективности, но также проигрывает им всем в дальности полёта. С показателем пассажировместимости 130 пассажиров в двухклассной компоновке пассажирского салона самолёт CS300 опережает самолёты A319-100SL, 737-700WL и 737MAX7, но проигрывает самолётам MC-21-200 и A319nео. В настоящее время в классе узкофюзеляжных самолётов вместимостью от 100 до 149 пассажиров в двухклассной компоновке пассажирского салона Bombardier CS300 является наиболее экономичным самолётом с показателем коэффициента топливной эффективности 0,0270791 л/(пасс·км).

Самолёт С919 выигрывает в части топливной эффективности у самолётов A320-200SL и 737-800WL, но проигрывает самолётам A320neo, 737MAX8 и МС-21-300, проигрывая всем пяти конкурентам по дальности полёта и пассажировместимости (кроме самолёта A320-200SL со 150 пассажирами).

Самолёт MC-21-300 имеет лучший показатель топливной эффективности по сравнению с самолётами A320-200SL, 737-800WL и C919, но проигрывает самолётам A320nео и 737MAX8. Вместе с тем, самолёт МС-21-300 проигрывает всем четырём конкурентам в части дальности полёта, но выигрывает по этому показателю у самолётов 737-800WL и C919. Также MC-21-300 превосходит самолётыконкуренты (A320-200SL существенно, 737-800WL и 737MAX8 незначительно) в части пассажировме-

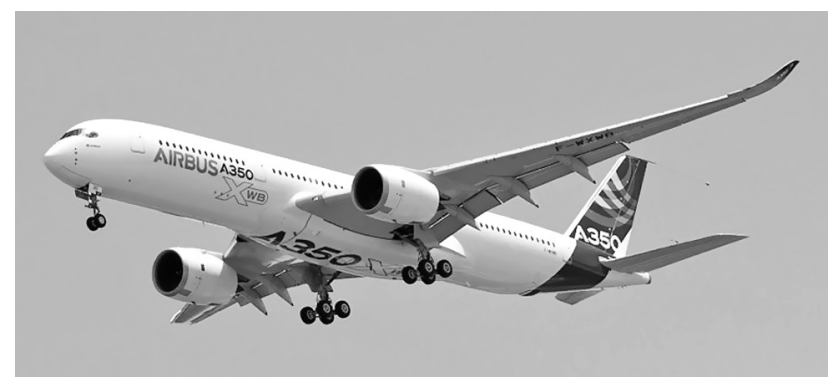

Рис. 6. Самолёт компании Airbus A350-900

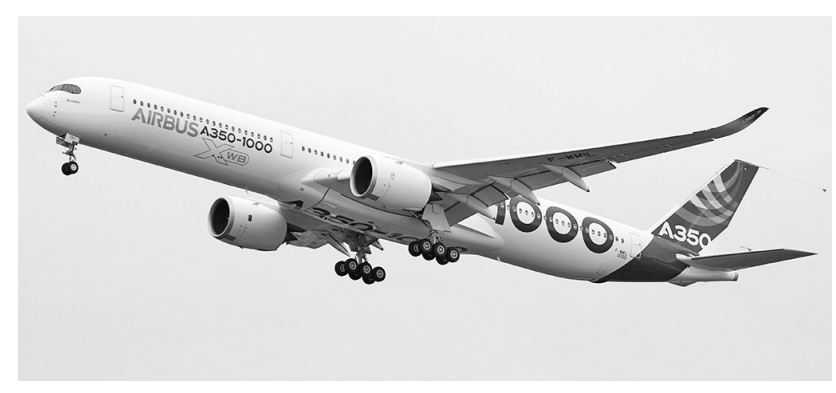

Рис. 7. Самолёт компании Airbus A350-1000 стимости, слегка уступая при этом самолёту A320neo.

Тем не менее, несмотря на появление новейших узкофюзеляжных пассажирских самолётов, наиболее экономичным самолётом в классе узкофюзеляжных самолётов с пассажировместимостью от 150 до 199 пассажиров в двухклассной компоновке пассажирского салона является самолёт Boeing 737MАХ9 с показателем топливной эффективности 0,0216456 л/(пасс·км) (см. таблицу 3).

\section{Анализ топливной эффективности новейших широкофюзеляжных самолётов}

За последнее время (2005-2017 годы) в части разработки и производства широкофюзеляжных самолётов продолжается конкуренция между двумя крупнейшими самолётостроительными компаниями мира, а именно Airbus и Boeing. Компания Airbus в период с 2005 по 2016 год разработала две модификации широкофюзеляжных самолётов А350-900 (см. рисунок 6) и А350-1000 (см. рисунок 7) [10], которые конкурируют с самолётами компании Boeing 777-200LR (Long Range) (см. рисунок 8) и 777-300ER (Extended Range) (см. рисунок 9), a также с самолётами 787-8, 787-9 и 787-10. Boeing ответил на появление самолётов А350-900 и А3501000 разработкой новых самолётов 777-8 (см. рисунок 10) и 777-9 (см. рисунок 11), стартовавшей в 2013 году [11]. При этом самолёт 777-8, по словам компании, конкурирует с А350-1000, а 777-9 является особенным самолётом, единственным в своём классе, конкурентов которому пока нет [12].

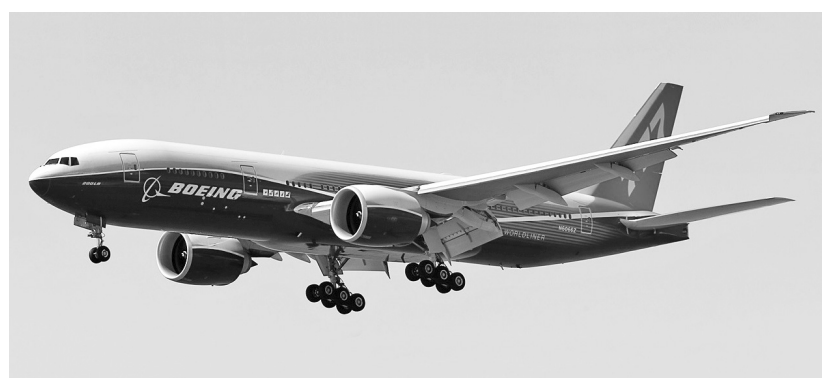

Pис. 8. Самолёт компании Boeing 777-200LR

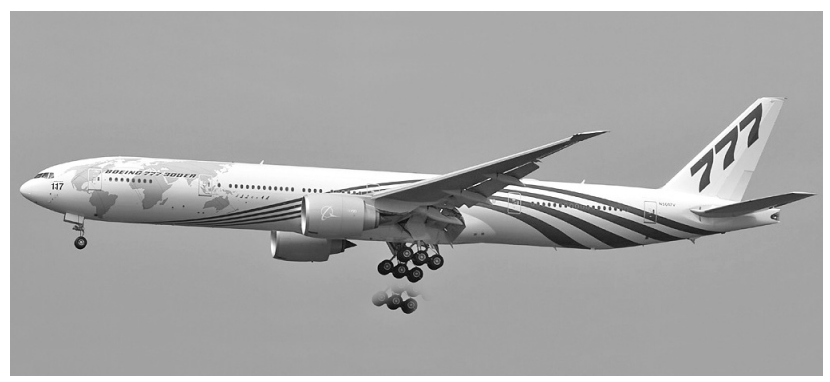

Рис. 9. Самолёт компании Boeing 777-300ER 


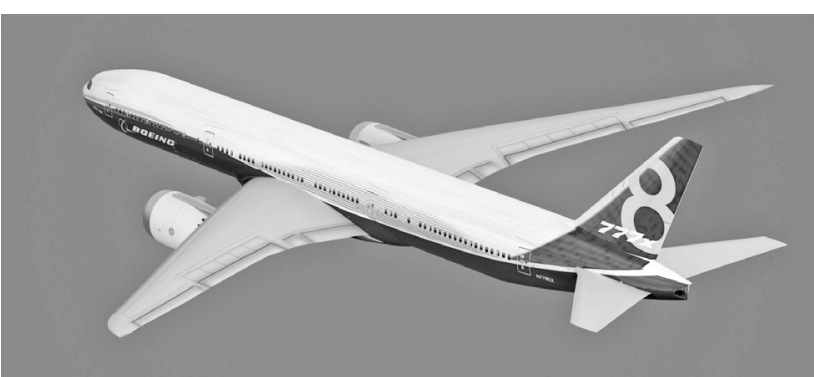

Рис. 10. Самолёт компании Boeing 777-8

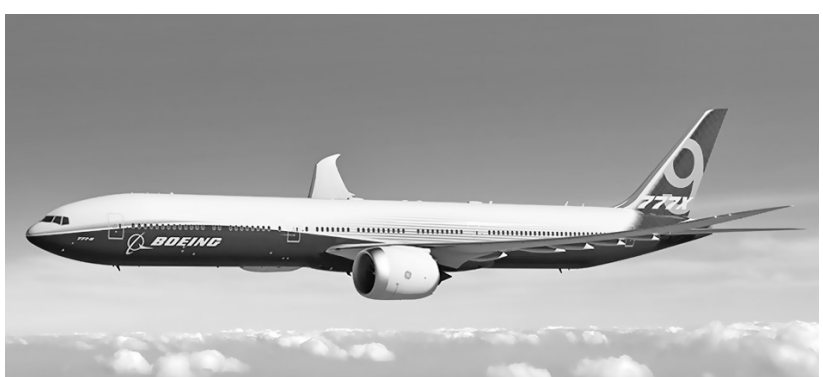

Рис. 11. Самолёт компании Boeing 777-9
Следует отметить, что в настоящее время (август 2017 года) серийно производятся и эксплуатируются только самолёты А350-900 (произведено и поставлено заказчикам около 100 машин) [13]. Самолёт А350-1000 совершил свой первый полёт в конце ноября 2016 года [14] и сейчас проходит цикл необходимых испытаний, а самолёты 777-8 и 777-9 в настоящее время находятся в стадии разработки и постройки опытных образцов (появление первого экземпляра 777-9 запланировано на конец 2019 года, а постройка первой машины 777-8 - на 2021...22 годы [11]).

В связи с такой ситуацией анализ топливной эффективности самолётов 777-8 и 777-9 проведён по предварительным данным, официально заявленным компанией-разработчиком, и представлен в таблице 8. Данные для расчётов взяты из [10] и [11].

Сравнение показателей топливной эффективности конкурирующих моделей широкофюзеляжных самолётов представлено в таблице 9 .

По результатам проведенных исследований можно констатировать, что самолёты компании Airbus A350-900 и А350-1000 превосходят в части топливной эффективности самолёты-конкуренты компании Boeing. Так самолёт A350-900 превосходит в части топливной эффективности самолёт 777-200LR на 8,53\% при одинаковой пассажировместимости в трёхклассной компоновке пассажирского салона и уступает ему в дальности полёта чуть более 2000 км. Самолёт А350-1000 превосходит своего конкурента 777-300ER на 6,16\% по топливной эффективности, но уступает ему в пассажировместимости (350 пассажиров против 386). Также А350-1000 незначительно превосходит 777-300ER в дальности полёта (14800 км против 14690 км). Кроме того, сравнение самолётов А3501000 и 777-8 также показывает превосходство самолёта компании Airbus в части топливной эффективности на 5,82\%, при этом А350-1000 незначительно уступает 777-8 в пассажировместимости (350 пассажиров против 353) и значительно уступает ему в дальности полёта (14800 км против 17220 км).

Хотя компания Boeing заявляет об исключительности самолёта 777-9 в своём классе, проведенное сравнение топливной эффективности указанного самолёта и ближайшего самолёта-конкурента А350-1000 показывает превосходство машины компании Airbus на 4,08\%. При этом самолёт 777-9 существенное превосходит А350-1000 в части пас-

Таблица 8

Анализ топливной эффективности широкофюзеляжных пассажирских самолётов

\begin{tabular}{|c|c|c|c|c|}
\hline Самолёт & $\boldsymbol{Q}_{\text {г }}$ & $\boldsymbol{L}$ & $\boldsymbol{n}_{\text {пасс }}$ & $\boldsymbol{k}_{\text {гэ }}$ \\
\hline- & {$[л]$} & {$[$ км $]$} & {$[$ пасс $]$} & {$[$ л/(пасс·Км $]$} \\
\hline A350-900 & 138000 & 14350 & 314 & 0.0306265 \\
\hline A350-1000 & 156000 & 14800 & 350 & 0.0301158 \\
\hline $777-200 \mathrm{LR}$ & 181283 & 17370 & 314 & 0.0332374 \\
\hline $777-300 \mathrm{ER}$ & 181283 & 14690 & 386 & 0.0319704 \\
\hline $777-8$ & 193712 & 17220 & 353 & 0.0318675 \\
\hline $777-9$ & 193712 & 15185 & 407 & 0.0313435 \\
\hline $747-8 \mathrm{I}$ & 239000 & 14800 & 467 & 0.0345795 \\
\hline
\end{tabular}


Таблица 9

Сравнение показателей топливной эффективности конкурирующих широкофюзеляжных самолётов

\begin{tabular}{|c|c|c|c|c|}
\hline Самолёт & $\boldsymbol{k}_{\text {тэ }}$ & Самолёт & $\boldsymbol{k}_{\text {тэ }}$ & Разница \\
\hline- & {$[$ л/(пасс·Км $]$} & - & {$[$ [л/(пасс·км $]$} & $\%$ \\
\hline $\mathrm{A} 350-900$ & 0.0306265 & $777-200 \mathrm{LR}$ & 0.0332374 & 8.53 \\
\hline $\mathrm{A} 350-1000$ & 0.0301158 & $777-300 \mathrm{ER}$ & 0.0319704 & 6.16 \\
\hline $\mathrm{A} 350-1000$ & 0.0301158 & $777-8$ & 0.0318675 & 5.82 \\
\hline $\mathrm{A} 350-1000$ & 0.0301158 & $777-9$ & 0.0313435 & 4.08 \\
\hline $777-9$ & 0.0313435 & $747-8 \mathrm{I}$ & 0.0345795 & 9.36 \\
\hline
\end{tabular}

сажировместимости (407 пассажиров против 350) и фактически попадает в категорию самолётов вместимостью от 400 до 600 пассажиров в трёхклассной компоновке пассажирского салона. Также самолёт 777-9 превосходит своего конкурента в дальности полёта (15185 км против 14800 км). В силу особенности самолёта 777-9 также проведено его сравнение с самолётом 747-8I (Intercontinental), при этом самолёт 777-9 превосходит 747-8I в части топливной эффективности на 9,36\% и дальности полёта (15185 км против 14800 км), уступая ему в пассажировместимости (407 пассажиров против 467). При этом следует отметить, что самолёт 747-8I оснащён четырьмя двигателями (см. рисунок 12), в отличие от всех других рассмотренных в данной статье широкофюзеляжных машин. Более корректно сравнить самолёт 777-9 с самолётом вместимостью более 400 пассажиров в трёхклассной компоновке пассажирского салона и оснащённым двумя двигателями на пилонах под крылом, но такого самолёта в настоящее время нет. Таким образом, самолёт 777-9 действительно является уникальной в своём классе машиной, о чём заявила компания Boeing.

Принимая во внимание проведённые исследования, можно констатировать, что наиболее экономичным широкофюзеляжным пассажирским самолётом с пассажировместимостью от 300 да 399 пас- сажиров в трёхклассной компоновке пассажирского салона в настоящее время является самолёт Airbus A350-1000 с показателем коэффициента топливной эффективности 0,0301158 л/(пасс·км). Наиболее экономичным самолётом среди широкофюзеляжных машин в классе пассажировместимости от 400 до 600 пассажиров в трёхклассной компоновке пассажирского салона является самолёт Boeing 777-9 с показателем коэффициента топливной эффективности 0,0313435 л/(пасс·км).

\section{Выводы}

Проведён анализ новейших пассажирских самолётов с точки зрения их топливной эффективности. Определены наиболее экономичные модели новейших узкофюзеляжных самолётов вместимостью 100...149 (Bombardier CS300) и 150...199 (Boeing 737MAX9) пассажиров в двухклассной компоновке пассажирского салона. Определены наиболее экономичные модели новейших широкофюзеляжных самолётов вместимостью 300...399 (Airbus A350$1000)$ и $400 \ldots 600$ пассажиров (Boeing 777-9) в трёхклассной компоновке пассажирского салона. Проведённые исследования могут быть полезны для авиакомпаний, формирующих маршрутную сеть полётов, исходя из пассажиропотоков на конкретных направлениях, при выборе моделей узко-

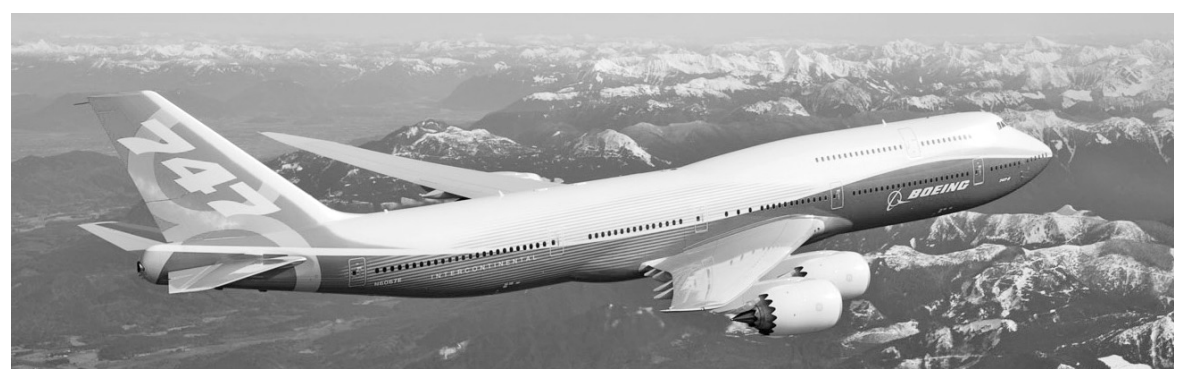

Pис. 12. Самолёт компании Boeing 747-8I 
и широкофюзеляжных пассажирских самолётов для собственного парка.

\section{Литература}

[1] P. M. Peeters, J. Middel, A. Hoolhorst «Fuel efficiency of commercial aircraft», National Aerospace University NLR of the Netherlands, 2005.

[2] S. Trimble «Swiss grades CS100 after four months in service», интернет сайт www.flightglobal.com, 29.11.2016.

[3] «Bombardier delivers first CS300 aircraft to AirBaltic», интернет сайт www.bombardier.com/media, 28.11.2016.

[4] K. Bradsher «China's new jetliner, the Comac C919, takes the first flight», Интернет сайт www.nytimes.com, 05.05.2017.

[5] «Новый пассажирский лайнер MC-21-300 совершил первый полёт», интернет сайт www.irkut.com/presscentre, 28.05.2017.
[6] Интернет сайт http://www.bombardier.com/en/aerospace/commercial-aircraft.html.

[7] Интернет сайт http://english.comac.cc/products/ca/.

[8] Интернет сайт http://mc21.irkut.com/program/.

[9] А. Н. Шаламов «Анализ топливной эффективности современных пассажирских самолётов», «Технологические системы», № 3(72)/2015.

[10] Интернет сайт http://www.aircraft.airbus.com/aircraftfamilies/passengeraircraft/a350xwbfamily/.

[11] Интернет сайт http://www.boeing.com/commercial $/ 777 \mathrm{x} /$.

[12] Boeing $777 \mathrm{X}$ to deliver unprecedented efficiency and economics», интернет сайт www.boeing.mediaroom. com, 18.11.2013.

[13] Интернет сайт http://www.aircraft.airbus.com/aircraftfamilies/passengeraircraft/a350xwbfamily/a350$900 /$.

[14] «First A350-1000 successfully completes first flight», интернет сайт www.airbus.com/newsroom/, 24.11.2016.

Shalamov A. N.

GECI GmbH. Germany, Hamburg

\section{FUEL EFFICIENCY ANALYSIS OF NEWEST PASSENGER AIRPLANES}

The fuel efficiency analysis of newest airplanes is performed. The most fuel efficient narrow-body airplanes are defined in the capacity range of $100 . .149$ and 150...199 seats in two class cabin configuration. The most fuel efficient wide-body airplanes are defined in the capacity range of $300 \ldots 399$ and $400 . .600$ seats in three class cabin configuration. [dx.doi.org/10.29010/080.5]

Keywords: airplane fuel efficiency; passenger airplane; narrow-body airplane; wide-body airplane; airplanes designing.

\section{References}

[1] P. M. Peeters, J. Middel, A. Hoolhorst «Fuel efficiency of commercial aircraft», National Aerospace University NLR of the Netherlands, 2005.

[2] S. Trimble «Swiss grades CS100 after four months in service», web site www.flightglobal.com, 29.11.2016.

[3] «Bombardier delivers first CS300 aircraft to AirBaltic», web site www.bombardier.com/media, 28.11.2016.

[4] K. Bradsher «China's new jetliner, the Comac C919, takes the first flight», web site www.nytimes.com, 05.05.2017.

[5] «New passenger airliner MC-21-300 took the first flight», web site www.irkut.com/press-centre, 28.05.2017.

[6] Web site http://www.bombardier.com/en/aerospace/commercial-aircraft.html.

[7] Web site http://english.comac.cc/products/ca/.

[8] Web site http://mc21.irkut.com/program/.

[9] A. N. Shalamov «Fuel efficiency analysis of modern passenger airplanes», «Technological systems», № 3(72)/2015.

[10] Web site http://www.aircraft.airbus.com/aircraftfamilies/passengeraircraft/a350xwbfamily/.

[11] Web site http://www.boeing.com/commercial/777x/.

[12] «Boeing 777X to deliver unprecedented efficiency and economics», web site www.boeing.mediaroom.com, 18.11.2013.

[13] Web site http://www.aircraft.airbus.com/aircraftfamilies/passengeraircraft/a350xwbfamily/a350-900/.

[14] «First A350-1000 successfully completes first flight», web site www.airbus.com/newsroom/, 24.11.2016. 